1| P a g e

Fanon's other children: psychopolitical and pedagogical implications

\title{
Erica Burman
}

Manchester Institute of Education

School of Environment, Education and Development

University of Manchester

Oxford Road

Manchester

M13 9PL

UK

Erica.Burman@manchester.ac.uk

www.discourseunit.com

accepted version of article appearing in Race, Ethnicity and Education

DOI:10.1080/13613324.2016.1150832 (published 9 March 2016) 


\title{
Fanon's other children: psychopolitical and pedagogical implications
}

\begin{abstract}
Discussions of the writings of theorist, psychiatrist and revolutionary, Frantz Fanon, in the fields of education and childhood typically focus on his account of a traumatic encounter with a white child, whose fear at the sight of a black man is said to create a vilified, racialized identity and installs an irreversible social and corporeal alienation. Yet Fanon's writings include a range of other depictions of children, childhood and education which reflect his broader views of colonial and decolonisation processes that include recognisable tropes of classic developmentalism, including gender chauvinisms. Nevertheless it is suggested that the diversity and complexity of child-related allusions across his texts allow for other critical readings that can inform educational debates on anticolonial analyses, of children, childhood and of their more general role in post and anti-development discourse.
\end{abstract}

Keywords: colonialism; decolonization; gender; generation; nationalism; development; psychopolitics. 


\section{Fanon's children ${ }^{1}$}

Children figure in complex and contested ways in colonial analyses, including the affects mobilised and exercised around them, while education can be a tool of colonial repression or emancipation. The child can represent a site of resistance to colonialism as much as the raw material for colonial exploitation or as vulnerable to the distortions of the brutalities of repression and war. In his various works, the psychiatrist and revolutionary theorist Frantz Fanon used a wide repertoire of child associations, including referring to children as subjects and agents in their own right, and in his first book Black Skin, White Masks (Fanon 1952/1970) (hereafter $B S W M$ ) even drawing on his own childhood and schooling memories to indicate complexities of racialised colonial subjectivity and identification in Martinique.

As discussed below, Fanon marked sharp political differentiations via the allocation of qualities associated with children according to how they were positioned under colonialism. Yet the most well-known association between Fanon and childhood is the scenario he describes in $B S W M$. This traumatic encounter marks the installation of a racialised identification, that is vilified even as it is constituted. He narrates how a child calls to his mother "Look, a Negro ${ }^{2}$.... I'm frightened" which precipitates for Fanon an existential crisis, a traumatic rupture in the relation not only between self and other, but between the now-blackened subject and his (or her) own body: "I took myself off from my own presence, far indeed, and made myself an object. What else could it be for me but an amputation, an excision, a haemorrhage that spattered my whole body with black blood?" (BSWM, 79), and "My body was given back to me sprawled out, distorted, re-coloured, clad in mourning that white winter day" (ibid. 80-81).

It is around this scene that Fanon frames his analysis of the "fact of blackness", ${ }^{3}$ that is, (corresponding to Fanon's phenomenological commitments, Desai 2014), the lived experience of 
inhabiting a body portrayed as primitive and dangerous: "I discovered my blackness, my ethnic characteristics; and I was battered down by tom-toms, cannibalism, intellectual deficiency, fetishism, racial defects, slave ships..." (BSWM, 79). Through recourse to this encounter with a white child and his mother, Fanon both highlights the insults and injuries wrought by racism and the psychic violence of coming to awareness of it.

The extensive discussion of this scene in literary, cultural and political theory has focused on the sexed and gendered character of the encounter between Fanon and the white woman and child, with the precise metaphorics mobilised by the child as a child left largely uninterrogated, ${ }^{4}$ even though educationalists have taken up Fanon's writing to discuss the wounds inflicted by such psychic violence (See, for example, Brenneman and Margonis 2012; Bingham 2006; Dutro and Bien 2014; Leonardo 2009; Leonardo and Porter 2010; Phoenix 2009; Tavares 2003; Watts and Erevelles 2004). In this paper I explore the wide range of childhood and educational motifs occurring in Fanon's writings ${ }^{5}$ to suggest that these not only illuminate more of Fanon's distinctive analysis of decolonisation, but can also offer resources for addressing current debates over the political ambiguities of discourses of childhood, gender, education and development.

Pivotal as the "'Look, a Negro!' scenario" (as Macey 2012 describes it) is within BSWM, and Fanon's writings more generally, this is not the only child that Fanon writes about. Alongside the white male child who installs or reproduces racism, and shows the cultural and affective transmission of colonial relations, there are other children and childhoods invoked, described and discussed by Fanon. Across Fanon's four books, I will present Fanon's rhetorics of childhood in three sections, differentiating between: The metaphorical child; The gendered and generationally-ordered child; and The empirical child. I draw these distinctions not to imply that 
they are mutually exclusive, but rather to indicate the range of uses to which Fanon puts his pedagogies of childhood, using the term 'pedagogy' to refer to the didacticism of his writings which, as will be seen below, do include some specifically educational considerations, as well as precisely avoiding these.

\section{The metaphorical child}

Children and childhood are appealed to across all sectors of culture, from the popular to the philosophical - although the latter tend to be more reflexive and sometimes playful or subversive in their treatments. Nevertheless many organicisms and romanticisations lurk within apparently innocent depictions (for example, Taylor 2013). Given the societally as well as intrapsychically invested character of childhood, arguably all appeals to 'the child' are metaphorical (Stainton Rogers and Stainton Rogers 1992), and most rhetorical deployments of childhood mobilise metaphor to further, covertly, their mode of argumentation. Karen Sánchez-Eppler (2005, xxiii) ${ }^{6}$ notes: "The relation between childhood as a discourse and childhood as persons has proven so entangled because American society has so frequently employed children to personal, emotional expression to social, institutional structures". An analytic task, then, is to render explicit the work done by the rhetorical appeal to childhood. As Massey $(1976,192)$ put it: "Unlike metaphor, which leaps to contact, interpretation recognises the inaccessibility of its object”. LesnikOberstein (2010) notes that presuming a clear distinction between 'the historical child' and 'the image Child' not only conflates two different domains of description, but doing so also disguises this move. This gives rise to two problems: "first [it is] fundamentally founded upon a split here between the historical child and the image Child, and then, again, in a figurative status which is acknowledged and addressed as not permitted to be acknowledged and addressed by us ('we')" (311). So despite, or rather precisely because of, the abstraction from specificities of culture, 
history and nationality that surround dominant mobilisations of childhood, they work as a vital repository for the maintenance and reproduction of particular, gendered, classed and cultural norms. It is these norms that a focus on Fanon's rhetorics of childhood can illuminate.

Fanon's final book, Wretched of the Earth (hereafter WE) was made (in)famous in part because the French philosopher and political theorist Jean-Paul Sartre wrote its Preface. Reflecting his paradoxical position as responsible for both publicising the book, ${ }^{7}$ and perhaps also contributing to its being banned (by representing Fanon's position on violence as more extreme than it actually was, as various commentators, including Macey 2012, and Hallward 2011, have noted), Sartre's formulation of the subject as finding him/herself through violent resistance goes beyond Fanon's, including in his depictions of childhood. This is Sartre in his Preface to $W E$ : "The child of violence, at every moment he draws from it his humanity. We were men at his expense, he makes himself man at ours: a different man; of higher quality" (20). In fact $W E$ offers both more diverse and nuanced accounts of both childhood and violence than Sartre allows, albeit in largely gender-free terms - with the generalised child figured as masculine.

The first essay of this book, 'Concerning violence', not only discusses the violence of the colonialist, rather than the revolutionary, but Fanon's iconography of childhood equates the figure of the child with incompetence and irresponsibility; that is, with being undisciplined, and greedy. These undesirable qualities, which are presented as childlike, are applied primarily to the colonizers and those who emulate them. He describes the colonialist bourgeoisie as "spoilt children"(WE, 37). ${ }^{8}$ But the colonized do not escape these negative childhood associations either, for the masses who feel deprived of goods are endowed with "a childlike process of reasoning" 
(ibid. 58). ${ }^{9}$ Here we see Fanon far from the romantic repertoire of childhood innocence associated with modern European thought.

There are more complicated images. While BSWM includes discussion of children's stories and folktales to highlight their pedagogical role in structuring racialised subjectivities and relationships, the only reference in $W E$ to a cultural artefact of childhood, in this case a fairy tale, occurs with the European being figured as a child in the world of make-believe, refusing to see that colonialism is over. "Concerning violence" ends with a call to recognize complicities with colonialism as follows: "To achieve this, the European peoples must first decide to wake up and shake themselves, use their brains, and stop playing the stupid game of the Sleeping Beauty" (84). The Europeans' sleep, or lack of awareness, is 'stupid' with both the discretionary and trivial character of 'game' queried alongside unsettling the superior brainpower usually claimed by Europeans. This complex description ruptures the narrative frame of the fairy tale, with its classed, gendered and heterosexual privilege, and its cultural presumptions, and perhaps also suggests that the rousing might involve more than a kiss.

Unsurprisingly, given Fanon's position as a secular modernist (Rabaka 2011), at times he mobilises a traditional progressivist model where the narrative of individual development is transposed to that of the new postcolonial state. The category 'youth' is presented as a synonym of newness, or of something insecurely established. ${ }^{10}$ He also writes about the problem of "young nations" (who "do not attract much private capital" WE, 81) and, in attending to the subjective psychopolitics of decolonisation, even discusses the racial prejudice of the "young national bourgeoisie" $(W E, 131){ }^{11}$

In relation to this, adulthood is portrayed within a traditional developmental discourse as a valued state of maturity, which is figured also as a consciousness that can be taught, as in: "The 
political education of the masses proposes not to treat the masses as children but to make adults of them" $(W E, 146)$. This is perhaps more surprising for its neoliberal cast: "The Algerian people is today an adult people responsible and fully conscious of its responsibilities. In short the Algerians are men of property" (WE, 155). It has been claimed that Fanon's mixture of critical socialist analysis and economic development discourse provides a better Marxist reading of processes of decolonisation and redevelopment (Rabaka 2011). Yet on first reading the recourse to traditional chronological age (and, as we shall see, gender) categories and status seems surprisingly conservative. In a similar vein, the chapter 'On national culture' discusses how "...these new forms are linked to the state of maturity of the national consciousness" $(W E, 196)$. We might note Françoise Vergès' (1997) psychobiographical account of the investments guiding Fanon's engagement with the Algerian revolution and for the gendered character of his focus: "Fanon's notion of masculinity presupposed a modernization of the Creole male through his entrance into a 'responsibilized' patriarchy. The Antillean male was weak; he danced and sang, mimicked the white man, when he should have seized a gun and fought" (594).

But far from merely uncritically reproducing this linear, lifecourse equation between individual and national development as triumphal or inevitable, Fanon turns it around with a discourse of the unnatural invoked in the service of political critique. In Chapter 2 of WE, "The pitfalls of national consciousness," he castigates the incipient national bourgeoisie for emulating its western counterparts, by suggesting that this reverses a natural ontogenetic path: "We need not think that it is jumping ahead; it is fact beginning at the end. It is already senile before it has come to know the petulance, the fearlessness or the will to succeed of youth" (123). Even as he subscribes to the ageism and disablism characteristic of modernising progressivist discourse (of precisely the kind that queer theorists of childhood have attempted to disrupt via the discourse of 
'growing sideways', Stockton 2009), Fanon mobilises this normative depiction of the chronological lifecourse to highlight its deviations. As he destabilises them, therefore, he also reinstates particular normativities.

In a further twist on, or even reversal of, the birth of the nation, in the context of decolonization, Fanon mobilises an accusatory image of the coloniser as a bad mother to the colonised nation in the way 'she' (note the woman-nation elision) suppresses expression of distress and protest, and alienates the colonised (her child) from "its very essence", so transferring the perversions of colonial oppression from the colonizer into the colonized. Here we see Fanon, the “psychoanalyst of culture” (see Gates' 1991, and Macey's 2012, critical evaluation) $)^{12}$ as well as revolutionary theorist, mobilizing an (arguably misogynist) image of the heteropatriarchal, mother-child relation:

On the unconscious plane, colonialism therefore did not seek to be considered by the native as a gentle, loving mother who protects her child from a hostile environment, but rather as a mother who unceasingly restrains her fundamentally perverse offspring from managing to commit suicide and from giving free reign to its evil instincts. The colonial mother protects her child from itself, from its ego, and from its physiology, its biology and its own unhappiness which is its very essence. (WE, 169-170)

Discourses of presumed maternal protection and perversion are subverted in the complex turns and connections forged between the individual, interpersonal, and the political through a critique of the evils of colonialism by showing how its rule (here rendered as maternal, alluding to the motif of the 'mothercountry') does not position the child as innocent. By portraying the child as always-already evil in the eyes of the colonizer ("evil instincts") insofar as it strives to understand its condition and so confronts its own misery, Fanon could be read as mobilising a 
discourse of lost or stolen childhoods. The child perverted by the (bad) colonial mother invites a call for a child free of such suicide-inducing contexts. Yet he stays short of making this move.

This is of a piece with Fanon's broader political perspective. Along with his opposition to spontaneism, and popular nationalism (notwithstanding his suspicions of colonial-trained native intellectuals), he was also a trenchant critic of nostalgic claims to a precolonial past, and appeals to some mythic common 'negritude'. ${ }^{13}$ As with his perspective on decolonisation, his rhetorics of childhood were less concerned with romanticising or returning to what went before than with transforming current conditions of oppression, exclusion and exploitation. ${ }^{14}$

Hence, contrary to the accusations of incitements to violence levelled at his analyses (which led to Wretched of the Earth being banned, although as indicated earlier this was probably more in reaction to Sartre's, than Fanon's, formulations), as educational engagements with Fanon's writings testify in making connections with questions of alienation, normalisation and the complex dynamics of multicultural teaching (see, for example, Bingham 2006; Dei and Simmons 2010; Huey-Li 2003; Leonardo and Porter 2010; Williams 1976), Fanon's primary concern was the impacts of the violence and distortions done to the oppressed/colonized, and his address was correspondingly to the colonized to oust these insults and inner psychic reproductions of the colonial state. He discusses the condition of the "native intellectual", who through colonialism (including colonial education) is oriented to western culture. He mobilises a discourse of misplaced "adoption" not merely to privilege naturalised biological kinship (aligned to national belonging), but rather to foreground the dynamics set in play by insecure roots or foundations: "Like adopted children who only stop investigating the new family framework at the moment when a minimum nucleus of security crystallizes in their psyche, the native intellectual will try to make European culture his own"(WE, 176). 
Unsurprisingly, given Fanon's commitment to a socialist vision of emancipation (Rabaka 2011; Gilroy 2010), any instrumentalisation of children and childhood that subordinates the child to the adult (worker, slave labourer) he will become is aligned with the coloniser. This occurs in the long quotation from Aimé Césaire's Les Armes miraculeuses, where "The Rebel” reports to the "The Mother" how the master said: "And all that man saw of my son's cradle was that it was a cradle of a chain-gang captain."(quoted in WE, 68). This anticipates, for example, Levander's (2006) discussion of the mutual articulation between the categories of adult and child and racialization as central to the elaboration of discourses of childhood in the US.

Similarly, the only occurrence of the equation of 'child' with 'primitive' is in a rare foray into a critique of modernity, when it is equated with its colonial, western forms. In $B S W M$ Fanon shifts narrative voice to mobilise the speaking position of the paternalist colonizer. Fanon refers to the trope of the colonized, seen as "the childhood of the world", "innocent", "ingenuous" and "spontaneous". He portrays such investments as arising from the psychic violence of modern western life, exemplified by life lived in "big buildings" - evoking both cities and the factories on which city wealth is built. Here cities are aligned with the colonial metropole, with a corresponding model of development as alienation.

Oh certainly I will be told, now and then when we are worn out by our lives in big buildings, we will turn to you as we do to our children - to the innocent, the ingenuous, the spontaneous. We will turn to you as to the childhood of the world. You are so real in your life - so funny, that is. Let us run away for a little while from ritualized, polite civilization and let us relax, bend to those heads, those adorably expressive faces. In a way, you reconcile us with ourselves. $(B S W M, 93)$

\section{The gendered and generationally-ordered child}


Recently, childhood studies has focused on childhood as a positional, relational status (rather than a state or stage), drawing attention in particular to generational relationships (Alanen 2005). Taking a more positional analysis of children and childhood in terms of family relationships, Fanon's second book, A Dying Colonialism, hereafter $D C$ ) explores the impacts of both colonialism and anticolonial struggle on family relations. In chapter 3 of $D C$ "The Algerian Family", Fanon takes in turn the various gendered and generational positions ("the son and the father", "the daughter and the father"), interestingly placing primacy on the younger party of each pair, perhaps as an expression of his secular modernist perspective, before discussing how political engagement and the modernising and empowering features of mobilisation transform 'the brothers', and "the couple". ${ }^{15}$ The trope of the hungry child, now so familiar from charity and aid campaigns (e.g. Black 1992), emphasises the disruption and violence done to 'The Algerian family'. Here the focus is on the distortions and transformations of family and kinship relations, made good by (secular) spiritual community: "Children scattered to the winds, innumerable orphans who roam about, haggard and famished" $(D C, 118)$, before concluding with stirring claims of how the struggle against tyranny will (re-) unite men and women as "a dispersed people is realizing its unity and founding in suffering a spiritual community which constitutes the most solid bastion of the Algerian Revolution" (DC, 119).

Gender is also a relational status (as well as involving power relations) and since, in Fanon's writings, the child is ostensibly gender-free but presumed masculine, gender is marked or topicalised largely only in relation to girls. So while (in 'The Algerian Family') there is no section on "The sisters", Fanon addresses in some detail the presumed or allotted lifecourse of girls in becoming women, ${ }^{16}$ the graduation to which, he argues, is - unlike the West - barely differentiated: "The life of an Algerian woman does not develop according to the three periods 
known in the West - childhood, puberty and marriage. The Algerian girl knows only two stages: childhood-puberty, and marriage... Considered a minor indefinitely, the woman owes it to herself to find a husband as soon as possible..." $(D C, 107)$. However the only reference to children as a reproductive and social burden to women as mothers is attributed to the colonizers: "Colonial society blazes up vehemently against this inferior status of the Algerian woman. Its members worry and show concern for those unfortunate women, doomed 'to produce brats;' kept behind walls, banned" $(D C, 40)$.

On the other hand, he subscribes elsewhere to the progressive nationalist, anticolonial and socialist narrative of revolutionary change as equivalent to female emancipation: as "restrictions ... knocked over and challenged by the national liberation struggle... The freedom of the Algerian people from then on became identified with woman's liberation, with her entry into history" ( $D C, 107)$. Significantly, the example of the Front Libération National (FLN) officers substituting for patriarchal fathers in giving permission for men and women in the Maquis (resistance) to marry $(D C, 115)$ is cited as a parable for modernisation and secularisation.

Chapter 2 of $D C$ is a remarkably prescient piece. "This is the Voice of Algeria" plots the political vicissitudes structuring the reception and engagement with new technologies, specifically the radio (discussed also by Painter 2012). Initially a key medium of colonial propaganda ("Before 1954, switching on the radio meant giving asylum to the occupiers' words", $D C$, 92), with ownership a sign of collaboration ("Having a radio meant being besieged from within by the colonizer", ibid.), this became a means of anticolonial communication that was vital to revolutionary mobilisation ("Having a radio meant seriously going to war", $D C, 93$ ). Curiously here the focus is only on the abstracted (generalised as male) Algerian, without explicit gender or status differentiations. The familiar trope of our times - of the young as more 
readily adaptive and receptive to new technology - is completely absent. Instead a unified national consciousness is explicitly addressed and presumed, spoken into being: "The Voice of Algeria, created out of nothing, brought the nation to life and endowed every citizen with a new status, telling him so explicitly" $(D C, 96)$. Here we see Fanon at his most democratically, if androcentrically, inclusive: the revolution is for everyone, the revolution changes and will liberate and emancipate everyone, old as well as young.

Fanon's treatment of women has generated much debate, particularly the first chapter of $D C$, "Algeria unveiled". This concerns the changing meanings of adopting and shedding the veil - as well as the motif of the violation and resistance strategies of the feminised body of the nation (see especially Haddour 2010). ${ }^{17}$ Even as he interrogates and in part explains the elision between woman and nation, Fanon reproduces it especially in the very title of the essay. To the European, "This woman who sees without being seen frustrates the colonizer. There is no reciprocity. She does not yield herself, she does not give herself, does not offer herself" $(D C, 44)$, so sexualized violence crucially includes unveiling: "Thus the rape of the Algerian woman in the dream of a European is always preceded by a rending of the veil. We witness here a double deflowering..." $(D C, 45)$. The gender-specific references soon fall away, however, making women and the veil function as a general metaphor for colonial oppression: "It is the white man who creates the Negro. But it is the Negro who creates negritude. To the colonialist offensive against the veil, the colonized opposes the cult of the veil" (DC, 47).

In this essay the only mention of the Algerian 'girl' is in the context of "the revolutionary character of the decision to involve all Algerian women" $(D C, 51)$, unmarried as well as married, but this was also because of "the more and more numerous volunteering of unmarried girls" (ibid.); that is, initiated by the young women themselves - an acknowledgement of their agency. 
Algerian women, especially the "young Algerian women", come to stand for the courage of the new revolutionary who literally goes to new places - entering previously inaccessibly geographies - for the cause. They are eulogised by Fanon. Maturity is depicted as a decolonisation that combines the intrapsychic with the political in Fanon's figuring of the transition from "child" to "Algerian woman, the young Algerian woman" $(D C, 52)$ :

... Each time she ventures into the European city, the Algerian woman must achieve a victory over herself, over her childish fears. She must consider the image of the occupier lodged somewhere in her mind and in her body, remodel it, initiate the essential work of eroding it, make it inessential, remove something of the shame that is attached to it, devalidate it. (ibid., emphasis added)

The young Algerian woman becomes the prototypical revolutionary subject who "whenever she is called upon, establishes a link. Algiers is no longer the Arab city ... From one area to another... the Revolution creates new links. More and more, it is the Algerian woman, the Algerian girl who will be assuming these tasks" $(D C, 53)$. The links here are geographical, spatially distributed connections, as well as interpersonal and intrapsychic. Here we need to recall how the veiling of women not only allowed women (and sometimes men dressed as women) to smuggle arms and explosives into French colonial strongholds for actions, but also how the French staging of coerced unveiling public events was carried out alongside the torture of men (and many women too). In a move relevant to current debates on the veil (Haddour 2013; Coloma 2013), Fanon comments: "What is in fact the assertion of a distinct identity, concern with keeping in fact a few shreds of national existence, is attributed to religious, magical, fanatical behaviour" $(D C, 41)$, but "... [t] he tenacity of the occupier in his endeavor to unveil the 
women, to make of them an ally in the work of cultural destruction, had the effect of strengthening traditional patterns of behaviour" $(D C, 49)$. While Fanon portrays gender roles in the traditional family as protective against colonization, he also highlights women's mobilization as central to the revolutionary struggle - not only via the traditional gendered roles of nurse or home-maker but also within armed struggle.

"Algeria Unveiled" concludes with the claim: "Side by side with us, our sisters do their part in further breaking down the enemy system and in liquidating the old mystifications once and for all" $(D C, 67)$. Alongside according a key place to women, this also positions them as separate (from 'us'), thereby mobilising, if also reworking for a new national culture, the longstanding discourse of women's greater responsibility for the production and reproduction of cultural identity (see e.g. Yuval-Davis 1998), now framed as "liquidating the old mystifications." So Fanon mobilizes traditional metaphorics of childhood and gendered adult-child relations, albeit in the service of illuminating the dynamics of colonization and how revolutionary struggle should challenge these. In doing so, he consolidates some - especially gendered and familial representations even as he also reverses others.

\section{The empirical child}

Many commentators on the iconography of childhood distinguish between metaphorical and 'historical', 'chronological' or 'flesh-and-blood' children. I mobilise the descriptor 'empirical' or 'chronological children' not despite, but precisely because of, the ways radical theorists of childhood (such as Edelman 2004) have been critiqued for inadvertently reinstating a naturalised developmental child whose politics of futurity is maintained without contestation (LesnikOberstein 2010). In this regard, Fanon is aligned less with an Edelman- style 'no future' (the title of his 2004 book), which explicitly elides individual and societal processes, than drawing 
attention to the partial ways in which specific children's futures are foreclosed, and in particular ways (as Pellegrini 2008, notes in relation to specific educational programmes). Indeed, the empirical status of being chronologically young is not necessarily a topic of age-related concern. Aside from its title, Fanon's "Letter to the Youth of Africa", published in his posthumous book Towards an African Revolution has no reference to any life-stage category; rather, the focus is on the political task and challenge of decolonisation at hand.

Yet Fanon also discusses chronological, or historical, children and young people. He expresses concern about the enforced idleness imposed on the youth of African countries: "The young people of an under-developed country are above all idle: occupations must be found for them" (WE, 158). Anticipating critiques of the ways black bodies are commodified and instrumentalised in capitalist sport, and also reflecting his perspective on racism as fetishism (Bhabha 1983), he comments: "The youth of Africa ought not to be sent to sport stadiums but into the fields and into the schools" (WE, 158). He warns of the young as being open to manipulation by "the various assaults made upon them by the very nature of Western culture" (ibid. 157-8).

While youth can be figured within a conventional nationalist narrative of progress, this does not escape a discourse of vulnerability that turns into victimhood. Yet agency remains prioritised over innocence and passivity in Fanon's documentation of the suffering of children, and the challenge posed by brutalized and militarized young people. In the Preface to A Dying Colonialism, Fanon reproduces a report from a Swedish journalist visiting an Algerian refugee camp. He writes:

Here is an extract from her report: 
The next in the line was a boy of seven marked by deep wounds made by a steel wire with which he had been bound while French soldiers mistreated and killed his parents and sisters. A lieutenant had forcefully kept the boy's eyes open, so that he would see and remember this for a long time....

This child was carried by his grandfather for five days and five nights before reaching the camp. The child said: "There is only one thing I want: to be able to cut a French soldier up into small pieces, tiny pieces!"

Does anyone think it is easy to make this child of seven forget both the murder of his family and his enormous vengeance? Is this orphaned child growing up in an apocalyptic atmosphere the sole message that French democracy will leave? $(D C, 26)^{18}$

The narrative of trauma links Fanon the psychiatrist/therapist ${ }^{19}$ with Fanon the anticolonial revolutionary and social pedagogue, via this account of a child who has been specifically victimised as a child with affective - now severed - bonds to his family members. He is "growing up" - note how the developmental maturational descriptor is in the continuous present that connects present to future - in an "apocalyptic atmosphere." 20 This atmosphere is imbibed by him, but not only him; this child is both specific and a token of many others, children and adults. What is left open is not only how possible, but also how desirable, it is to make "this child of seven forget".

This formulation - in both psychotherapeutic and political senses - offered by Fanon counters a reading of inciting or romanticising violence, even as it also admits this as a likely reaction. Indeed Wretched of the Earth ends with Fanon, the psychiatrist or mental health practitioner, presenting medical case histories cataloguing of psychological casualties and disturbances created by both chronic colonial repression and then the horrors of the massacres, 
battles and torture with which the revolutionary struggle was met. ${ }^{21}$ Fanon's radical humanism (Gilroy 2010) is seen in how he ran his wards at Blida-Joinville which, during the revolution, which became a space of sanctuary not only for those distressed by political events but also for revolutionaries in need of hiding, and in need of psychological treatment for being tortured (see e.g. Giordano 2011; Keller 2007; Razanajao, Postel and Allen 1996). Even the torturers sought out his help - Fanon describes a police chief whose symptoms were interfering in his capacity to carry out his torturing duties.

Children appear in these 'Cases', in three ways. Firstly, from the perspective of adults. Along with psychosomatic headaches, lack of appetite, reports of impotence, he documents a case of a man who had an "...irresistible impulse to tear up a photo of his little girl" (WE, 206), from which emerges the story of going into hiding and guilt that his wife had been raped by French soldiers in his absence. Fanon interprets the desire to eradicate the representation of his offspring as a symptom whose metonymic links lead from the girl to much more longstanding and ambivalent dynamics of his relationship with his wife. Secondly, there are reports, unsurprisingly, of similar psychosomatic symptoms affecting younger children, as "Case 4. Behaviour disturbances in young Algerians of under ten" who have "marked love for parental images, noise phobia, sleeplessness and sleep walking, enuresis, sadistic tendencies"(WE, 223-4). Thus it is the adult-child relation and the impacts of its disturbance that is foregrounded here (rather than privileging any particular depiction of children, or childhood, or what these should be).

In "Series B" Fanon presents "certain cases of groups of cases in which the event giving rise to the illness is in the first place the atmosphere of total war which reigns in Algeria" (WE, 217). Fanon's psychopolitical diagnosis (of "the atmosphere of total war") is a clear intervention, 
since the French state failed to acknowledge the Algerian revolution as a war then, and scarcely now. His concern is with the psychic conflicts produced by the political repression. In Case 3 , he reports on "Neurotic attitude of a young Frenchwoman whose father, a highly placed civil servant, was killed in an ambush". Her father was a torturer, and her symptoms arise from her conflicted relationship with him as she knew what kinds of activities he had been involved with, with her sympathies lying with the oppressed Algerian people. Indeed she comments: "If I were an Algerian girl, I'd be in the Maquis" (WE, 223).

Most notably, "Series B, Case 1," describes the murder of a European boy by two Algerian boys, of thirteen and fourteen years old respectively. Fanon presents verbatim cross examinations of these boys, the efforts of the questioner to establish whether they knew what they were doing, and to establish a motive. They admitted the crime, and claimed that there was no specific interpersonal precipitant, except their own desire to kill a European: "We weren't a bit cross with him...He was a good friend of ours" (WE, 217). They are quoted as saying: "One day we decided to kill him because the Europeans want to kill all the Arabs. We can't kill big people. But we could kill ones like him, because he was the same age as us..." (WE, 217-8). This Case graphically presents psychological processes of depersonalisation and psychic splitting instigated by French repression, for the boys appear rational, and indeed claim responsibility for their actions even though they were unable to account for the contradiction between the European boy as their friend and deciding to kill him.

Finally, Fanon directly confronts the racial stereotyping of the French 'Algerian school' of psychiatry that prevailed at that very time, associated with Porot. While the latter puts forward models justifying colonial domination, Fanon provides other explanations of the phenomena the colonial psychiatrists presented as evidence of the inherent madness, inferiority, or 
untrustworthiness of Algerians, highlighting how hunger and economic insecurity undermine humanity, and even human consideration of children. ${ }^{22}$ This is then used to highlight how colonial oppression turns people, even family members against each other:

...the natives fight among themselves. They tend to use each other as a screen, and each hides from his neighbour the national enemy. Then, tired out after a hard sixteen-hour day the native sinks down to rest on his mat, and a child on the other side of the canvas partition starts crying and prevents him from sleeping, it so happens that it is a little Algerian. When he does to beg for a little semolina or a drop of oil from the grocer to whom he already owes some hundreds of francs, and when he sees that he is refused, an immense feeling hatred and an overpowering desire to kill rises within him.... (WE, 248)

\section{Child as other, othering children}

Longstanding colonial dynamics link children with the colonised. Both 'child' and 'primitive'/colonised have been figured as other to, but also as true version of, the industrialised, western self. The articulation of these two tropes is far from accidental, since patriarchal domination of the family, which positioned women and children as ruled by the husband/father, was used as the naturalised model for colonial domination (McClintock, 1995). As Levander (2006, 2-3) argues: "The child works to establish race as a central shaping element of ostensibly raceless Western ideals. Excavating the child's importance to the development of white supremacy is urgently needed". Dominant discourses of development originate in portraying white European middle class men as their pinnacle, a dynamic that discourses and technologies of crossnational comparison always evoke (Burman 2005, 2007, 2008), even as they may rework and reinterpret them. They could also be replayed at home precisely in relation to child welfare agendas - hence Monica Flegel (2009) notes how in its early days the UK National Society for 
the Prevention of Cruelty to Children (NSPCC) mobilised discourses of 'savagery' to apply to neglectful British working class parents, whilst also drawing on Christian imagery of the Holy Family to figure child nurture and support.

This common pedagogical motif has been mobilised in critiques of models of childhood, where postcolonial analyses have been applied to analyse and challenge the paternalism and incompetency accorded children, childhood and the young. ${ }^{23}$ These have been inspired by analyses of colonialism and postcolonialism, in particular Said (1978), to indicate common dynamics of attributions of authenticity and unmediated access to nature, truth, and collective and individual corporeal well-being that arise as reverse tropes of the damaged subjectivities produced by modern western capitalism; that is, of alienation from nature, from our own bodies, and from each other. Yet analysing Kipling's literary depictions of children, Sue Walsh $(2010,33)$ suggests "...the concept of the 'child', especially as applied to the colonized subject, may have unlooked for and potentially destabilizing implications in the figurations of colonial ventures. What, for example, are the implications of the child/colonized analogy if the child's positioning as adult-in-waiting is allowed to feed through to the conception of the colonized?"

The abstracted concept of childhood has itself been separated or alienated from the material lives of historical children, who nonetheless both know and know their non-normative relation to this category. In linking the condition of childhood and the colonized, what is left uninterrogated is the specific situation of children under colonialism which, as Ann Stoler (2002) shows, is complicated by the complexities thrown up by colonial regulations of intimate relations surrounding children as well by the affective ties to children that sometimes motivate their transgression. From her close analysis of the colonial archive of the Dutch East Indies, she argues for the methodological and political importance of reading for ambivalence and 
complexity rather than presuming as real the colonial performances that precisely aimed to suppress such ambiguities. $^{24}$

In this article I have attended to ambiguities in, and instabilities of, Fanon's metaphorics of childhood, to maintain awareness of their diverse political dynamics. The tripartite differentiation of metaphorical, gender/generational status and empirical childhood identified here both arise from and promote different pedagogical modes of address and engagement. Clearly Fanon's depictions could be categorised within a modern, nationalist frame, since he so readily mobilises the young as the future of the nation, also including particular gender chauvinisms and heterosexed norms. Yet his hostility to models of western development on which, arguably, many models of child as well as economic development rely, makes for more complex possibilities. Without forcing an overstatement of his radical imaginary of children and childhood, I suggest readings can be retrieved that remain open or uncommitted about children, childhood and the relationship between childhood and political and economic development; readings that are politically - and in these times where education is so tied to fixed and instrumental agendas, also pedagogically - fruitful. Clearly significant is Fanon's opposition to origin narratives, whether of lost childhoods or lost national developments.

Fanon's rhetorics of childhood and development pressurise the child-other relation arguably as much as, and as a reflection of, his analysis of the self-other relation produced in terms of structures of racialised symbolic and structural violence (Ghassan 2010). His depictions provoke re-evaluation of whether and how what happens after decolonisation departs from, or reproduces, dominant models of development in moving from the designation 'underdeveloped' to 'developed' or to something else, opening up space for discussion about the role for education (or indeed 'counter education', Brenneman and Margonis 2012). More recent terminology of 
'majority/minority world' or 'rich/poor countries' attends to geographical and economic questions of distribution, and sidesteps vexed questions of teleology that would otherwise be posed (as indicated also by formulations such as 'transitional', 'emerging' and - in some cases 'failed' (Bilgin and Morton 2002).

It is a moot point whether and, if so, how the conditions of children's lives and the political-economic level accorded the countries they live in should be connected. Some critics of development(al) discourse have called for their disaggregation, as one of the many ways children subjectivities and current (social and educational) conditions are instrumentalised and subordinated to economic-national priorities, as indicated in particular ways by neoliberalism (see Ailwood 2008; Fendler 2001). Yet those countries that in Fanon's time were becoming newly independent from colonial rule are now precisely those whose populations are chronologically young, while the over-developed rich countries face the crisis of caring for an aging (and presumed economically less productive) population.

Fanon's repertoire of discursive tropes of the child provide resources to explore anticolonial or revolutionary metaphorics of childhood, even as his diverse formulations do not allow for easy resolution. He neither offers an alternative metaphorics, which would in any case risk reinstating equivalent exclusions and normalisations, nor is his depiction mere repetition of old oppressive models. I have suggested that Fanon's playful use of familial, relational, generational discourses reverses, as well as recapitulates, prevailing understandings of age and chronological as well as sexed, gendered and other power relations. ${ }^{25}$ Such unsettlings could be read as deconstructionist; denaturalising assumed positions and arrangements, and so revealing more about their precise and contingent configurations. Yet Fanon is also a modern developmentalist, formulating policies to turn the young of the nation into "mature" ("conscious", 
"responsible") adults, albeit that sometimes the 'Youth' are addressed less as deficient and vulnerable but as the future national subjects and agents. In both his clinical psychiatric writings and his cultural psychopolitical analysis evoking racialised subjectivities, he draws on a psychodynamic understanding of childhood experience as formative - and he uses this for the depiction of dystopian (“apocalyptic") future social-political relations. Fanon's children therefore not only include the child of '"Look, a Negro!"', that is, a child tainted by racism, whose ventriloquism (Macherey 2012) works to emphasise the violence done to the agents and heirs of racist rule as well as its victims. Rather, as with in his other depictions of dangerous and damaged children and childhoods, Fanon accords agency to children, as societal participants, whether as morally responsible or culpable, inviting (as Dei and Simmons 2010 and Maldonado

et al. 2005 note) questions of practical engagement. Whether addressing post-conflict militarized youth, or envisaging post-racist societies, Fanon's narrative strategies for traversing the childcolony relation continue to offer some significant conceptual-political resources.

\section{REFERENCES}

Ailwood, Joan. 2008. "Learning or earning in the 'Smart State'". Childhood: a global journal of child research 15 (4): 535-551.

Alanen, Leena. 2005. "Childhood as generational condition." In Childhood: Critical Concepts in Sociology Volume 3, edited by Chris Jenks, 286-305. London: Routledge.

Burman, Erica. 2005. "Engendering culture in psychology." Theory \& Psychology 15 (4): 527548.

Burman, Erica. 2007. "Between orientalism and normalisation: cross-cultural lessons from Japan for a critical history of psychology." History of Psychology 10 (2): 179-198.

Burman, Erica. 2008. Developments: child, image, nation. London: BrunnerRoutledge. 
Burman, Erica. in press. "Educational intimacies: writing bodily relations in early childhood and education.” In Metodefestival og Øyeblikksrealisme [Method-celebration/party and moments of realism, edited by Anne Beate Reinertsen and Ann Merete Otterstad. Oslo: Fagbokforlaget.

Burman, Erica. submitted. "Fanon's interpellation: by the child, and of Lacan"

Bhabha, H. 1983. "The other question: the stereotype and colonial discourse." Screen 24 (6): 1836.

Bilgin, Pinar, and Adam Morton. 2002. "Historicising representations of 'failed states': beyond the cold-war annexation of the social sciences?." Third World Quarterly, 23 (1): 55-80.

Bingham, Charles. 2006. "Before recognition and after: the educational critique." Educational Theory 56 (3): 325-344 DOI: 10.1111/j.1741-5446.2006.00229.x;

Black, Maggie. 1992. A cause for our times: Oxfam-the first fifty years. Oxford: Oxfam.

Boler, Megan. 1997. "Disciplined emotions: philosophies of educated feelings", Educational Theory 47 (2): 203-237

Brenneman Mark and Frank Margonis. 2012. "Degrees of disenchantment: a review essay." Educational Theory 62 (2): 225-247, DOI: 10.1111/j.1741-5446.2012.00444.x

Cannella, Gaile. and Rhadika Viruru. 2004. Childhood and Postcolonization. New York: RoutledgeFalmer.

Coloma, Roland Sintos. 2013. "Empire: analytical category for educational research." Educational Theory 63 (6): 639-658.

Dei, George J. Sefa and Marlon Simmons. (Eds.) 2010. Fanon \& Education: thinking through pedagogical possibilities. New York: Peter Lang. 
Desai, Miraj U. 2014. "Psychology, the psychological, and critical praxis: a phenomenologist reads Frantz Fanon". Theory \& Psychology 24 (1): 58-75.

Dutro Elizabeth and Andrea C. Bien. 2014. "Listening to the Speaking Wound: A Trauma Studies Perspective on Student Positioning in Schools." American Educational Research Journal 51 (1): 7-35.

Edelman, Lee. 2004. No Future. Durham: Duke University Press.

Fanon, Franz. 1952/1970. Black skin, white masks. Translated by Charles L. Markmann. London: Paladin.

Fanon, Franz. 1959/1965. A Dying Colonialism. Translated by Haakon Chevalier. New York: Grove Press.

Fanon, Franz. 1961/1963. The Wretched of the Earth. Translated by Constance Farrington. London: Penguin.

Fanon, Franz. 1964. Toward the African revolution: political essays. Translated by Haakon Chevalier. New York: Grove Press.

Fendler, Lynne. 2001. "Educating flexible souls: the construction of subjectivity through developmentality and interaction." Governing the Child in the New Millenium, edited by Kenneth Hultqvist and Gunilla Dahlberg, 119-142. New York and London: RoutledgeFalmer.

Flegel, Monica. 2009. Conceptualizing Cruelty to Children in Nineteenth-Century England. London: Ashgate.

Gates, Henry. Louis. 1991. "Critical Fanonism." Critical Inquiry 17 (3): 457-470.

Giordano, Cristina. 2011. "Translating Fanon in the Italian context: Re-thinking the ethics of treatment in psychiatry." Transcultural Psychiatry 48 (3): 228-256. 
Gilroy, Paul. 2010. "Fanon and Améry: theory, torture and the prospect of humanism." Theory, Culture \& Society 27 (7-8): 16-32.

Haddour, Azzedine . 2010. "Torture unveiled: rereading Fanon and Bourdieu in the context of May 1958." Theory, Culture \& Society 27 (7-8): 66-90.

Hage, Ghassan. 2010. "The affective politics of racial mis-interpellation." Theory, Culture \& Society 27 (7-8): 112-129.

Hallward, Peter. 2011. "Fanon and political will." Cosmos and History: the Journal of Natural and Social Philosophy 7 (1): 104-127.

Huey-Li, Li . 2003. "Bioregionalism and global education." Educational Theory 53 (1): 55-73.

Khanna, Ranjana. 2004. Dark Continents: psychoanalysis and colonialism. Durham: Duke University Press.

Khanna, Ranjana 2013. "The lumpenproletariat, the subaltern, the mental asylum." The South Atlantic Quarterly 112 (1): 129-143.

Lebeau, Vicky. 2005. "Children of violence", in Frantz Fanon's Black Skin White Masks: interdisciplinary essays, edited by Max Silverman, 128-145. Manchester: Manchester University Press.

Leonardo, Zeus 2009. Race, Whiteness, and Education. New York: Routledge.

Leonardo, Zeus and Ronald Porter. 2010. "Pedagogy of Fear: Toward a Fanonian Theory of Safety in Race Dialogue." Race, Ethnicity and Education 13 (2): 139-157.

Lesko, Nancy. 1996. "Past present and future conceptions of adolescence." Educational Theory 46 (4): 453-472.

Lesnik-Oberstein, Karin. 2010. Childhood, queer theory, and feminism. Feminist Theory 11 (3): 309-321. 
Levander, Caroline. F. 2006. Cradle of Liberty: Race, the Child, and national Belonging from Thomas Jefferson to W.E.B. DuBois. Durham and London: Duke.

Levinson, Natasha. 1997. "Teaching in the midst of relatedness: the paradox of natality in Hannah Arendt's educational thought." Educational Theory 47 (4): 435-451.

Keller, Richard. 2007. "Clinician and revolutionary: Frantz Fanon, biography, and the history of colonial medicine." Bulletin of the History of Medicine, 81 (4): 823-841.

Macey, David. 2010. "'I am my own foundation': Franz Fanon as a source of continued political embarrassment." Theory, Culture and Society 27 (7-8): 33-51.

Macey, David. 2012. Frantz Fanon: a biography. London: Verso.

Macherey, Pierre. 2012. "Figures of interpellation in Althusser and Fanon." Radical Philosophy 173: 9-20.

Massey, Irving. 1976. The Gaping Pig: literature and metamorphosis. Berkeley: University of California Press.

McClintock, Anne. 1995. Imperial leather: Race, gender, and sexuality in the colonial contest. New York: Routledge.

Maldonado, David E Z, Robert Rhoads, and Tracy L. Buenavista. 2005. "The Student-Initiated Retention Project: Theoretical Contributions and the Role of Self-Empowerment." American Educational Research Journal 42 (4): 605-638.

Painter, Desmond. 2012. "Occupy Words: Language, Commodification, and the (Re)Appropriation of Voice." The Second Marxism and Psychology Conference, Morelia, Mexico, August.

Pellegrini, Ann. 2008. "'What Do Children Learn at School?' Necropedagogy and the Future of the Dead Child." Social Text 26 (4): 97-105. 
Phoenix, Ann. 2009. "De-colonising practices: negotiating narratives from racialised and gendered experiences of education." Race, Ethnicity and Education 12 (1): 101-114.

Rabaka, Riyad. 2011. "Revolutionary Fanonism: On Frantz Fanon's modification of Marxism and decolonization of democratic socialism." Socialism and Democracy 25 (1): 126-145.

Razanajao, C.L., Postel, J. \& Allen, D.F. 1996. "The life and psychiatric work of Frantz Fanon." History of Psychiatry 7: 499-524.

Rose, Jacqueline. 1984. The case of Peter Pan, or, The impossibility of children's fiction. Pennsylvania: University of Pennsylvania Press.

Said, Edward. 1978. Orientalism. New York: Vintage.

Sánchez-Eppler, Karen. 2005. Dependent States: The Child's Part in Nineteenth-Century American Culture: University of Chicago Press.

Stainton Rogers, Rex. and Wendy Stainton Rogers. 1992. Stories of Childhood: shifting agendas of child concern. Lewes: Harvester Wheatsheaf.

Steedman, Carolyn. 1995. Strange dislocations: Childhood and the idea of human interiority, 1780-1930. London: Virago.

Stockton, Kathryn. 2009. Growing sideways. Durham: Duke.

Stoler, Ann Laura. 2002. Carnal Knowledge and imperial rule. Berkeley: University of California Press.

Tavares, Hannah, M. 2003. "Reading in the wake of postcoloniality: constructing "race" in public education in the U.S. territory of Hawai'i." Educational Theory 53 (4): 437-452;

Taylor, Affrica. 2013. Reconfiguring the natures of childhood. London: BrunnerRoutledge. Vergès, Françoise 1996. "The heritage of Frantz Fanon." The European Legacy 1 (3): 994-998. 
Vergès, Françoise. 1997. "Creole skin, Black mask: Fanon and disavowal." Critical Inquiry 23 (3): $578-596$.

Walsh, Sue. 2010. Kipling's children's literature: language, identity and constructions of childhood. Farnham, Surrey: Ashgate.

Watts, Ivan Eugene and Nirmala Erevelles. 2004. "These Deadly Times: Reconceptualizing School Violence by Using Critical Race Theory and Disability Studies." American Educational Research Journal 41 (2): 271-299.

Williams, David C. 1976. "Ressentiment and schooling." Educational Theory 26 (1): 72-80. Yuval-Davis, Nira. 1998. Gender and nation. London: Sage.

\footnotetext{
${ }^{1}$ It is beyond the scope of this paper to discuss Fanon's actual, biological paternal role, although he did father a son, Olivier, and daughter, Mireille. See Macey (2012) for an authoritative biography.

${ }^{2}$ Macey (2012) discusses the ambiguities and different nuances of racialization/racism mediated by translation, offering his own versions of key passages. While he translates Fanon's original term négre as 'negro', he notes that the French term carries (even) more offensive nuances than this English word.

${ }^{3}$ This is the title of the chapter in which this appears in Black Skin, White Masks.

${ }^{4}$ An exception to this is Lebeau (2005) who motivates for an object relations psychoanalytic reading.

${ }^{5}$ The English language titles of the four texts Fanon authored are: Black skin, white masks, A Dying Colonialism note that the French title of this was L'An Cinq de la Révolution), The Wretched of the Earth - and Toward the African revolution: political essays. The first three were published in his lifetime, while the final posthumous collection of his - retrospectively identified - political writings was first published in 1964 (published in translation in 1967).

${ }^{6}$ While Sánchez-Eppler is discussing the US context, she draws on influential British and European analyses, especially Rose (1984) and Steedman (1995).
} 
${ }^{7}$ Wretched of the Earth was banned shortly after publication in France, across most of Latin American and South Africa. Macey (2012) devotes considerable discussion to evaluating the impact of Sartre's Preface, and its role in promoting key misunderstandings of Fanon's ideas (especially in relation to the role he accords violence), see also his evaluation in Macey (2010). Sartre was, of course, writing about his own ideas, not Fanon's - albeit that his Preface was intended to be supportive of Fanon and to promote the book, and that Fanon was also highly influenced by Sartre's writings (see also Desai 2014).

8 "We find intact in them the manners and forms of thought picked up during their association with the colonialist bourgeoisie. Spoilt children of yesterday's colonialism and of today's national governments, they organize the loot of whatever national resources exist" (WE,37).

9 "The masses by a sort of (if we may say so) childlike process of reasoning convince themselves that they have been robbed of all these things," (WE,58).

${ }^{10}$ As where "the young national bourgeoisie", is developed in terms of an image of gang warfare: "The behaviour of the young national bourgeoisie of certain under-developed countries is reminiscent of the members of a gang, who after every hold-up hide their share in the swag from other members who are their accomplices..." (WE, p.139).

${ }^{11}$ Indeed the only time a chronologically older category of childhood, 'adolescence', is invoked in Wretched of the Earth is in relation to an account of misplaced revolutionary defiance which, while presented as understandable (indicating some developmentally-implied indulgence), is seen as foolhardy: "The flagrant refusal to compromise and the tough will that sets itself against getting tied up is reminiscent of the behaviour of proud, poverty-stricken adolescents, who are always ready to risk their necks in order to have the last word" (WE, 65).

12 The phrase comes from Gates (1991: 458). The extent to which Fanon subscribed to and indeed practised any form of psychoanalytic approach is a moot point, and Macey's (2012) account is scathing of attempts to read Fanon in this way. However, clearly such readings can be made, in particular of Fanon's citations and interpretations of Lacan. See Khanna (2004) and, for a critical evaluation, Burman, submitted. 
${ }^{13}$ Fanon participated in some of the major literary debates among African writers on this topic to state this view. Indeed his chapter 'On national culture' in WE was his contribution to the Second Congress on Black Artists and Writers held in Rome in 1959.

14 "A national culture in under-developed countries should therefore take its place at the very heart of the struggle for freedom which these countries are carrying on. Men of African cultures who are still fighting in the name of African-Negro culture and who have called many congresses in the name of the unity of that culture should today realize that all their efforts amount to is to make comparisons between coins and sarcophagi. There is no common destiny to be shared between the national cultures of Senegal and Guinea; but there is a common destiny between the Senegalese and Guinean nations which are both dominated by French colonialism" (WE,188). This did not mean that national culture was irrelevant, but rather that national consciousness would produce new forms of culture. For the sentences before assert: "A national culture is not a folklore, nor an abstract populism that believes it can discover the people's true nature. It is not made up of the inert dregs of gratuitous actions, that is to say actions which are less and less attached to the ever-present reality of the people. A national culture is the whole body of efforts made by a people in the sphere of thought to describe, justify and praise the action through which that people has creates itself and keeps itself in existence." (WE,188) His 'statement' concludes by claiming: "A nation which is born of the people's concerned action and which embodies the real aspirations of the people while changing the state cannot exist save in the expression of exceptionally rich forms of culture." (ibid. 198) ${ }^{15}$ Since this book was first published in 1959 under the title L'An Cinq, de la Révolution, Fanon also assesses the pressures the revolutionary struggle has put on marital relations, including divorce and dispersal, with accounts of a wife dealing with the return of her tortured husband whose mind has been shattered, a husband knowing that his wife was imprisoned and will have been raped.

16 "The woman's life in the home, made up of century's old customs, allows no innovation. Illiteracy, poverty, the status of an oppressed people, maintain and strengthen the specific features of the colonized universe, to the point of changing their nature entirely. The girl adopts automatically the behaviors and role of Algerian feminine society", (DC, 106). 
${ }^{17}$ Haddour (2010) situates Fanon's discussion in relation to the actual practice of veiling and unveiling as they figured in the Algerian revolution - both in terms of its use as a disguise to travel into French zones and also the strategy of forced unveilings - alongside beatings and rapes - used by the French in their brutal counterrevolutionary responses.

${ }^{18}$ This extract is also discussed at some length by Khanna (2013).

${ }^{19}$ Various recent commentaries have both commented on the significance of omitting, and attended to, his work and writing as both clinician and revolutionary. Fanon was trained as a psychiatrist. As Macey (2012) notes, he practised in both innovative ways (introducing social or institutional psychotherapy wherever he worked - in Algeria, Morocco and Tunisia), as well as also using psychopharmacological approaches and even electroconvulsive therapy.

${ }^{20}$ Khanna (2013) among others, also discusses this example.

${ }^{21}$ These are not, formally, medical histories, even though they are presented in a taxonomy with putatively differentiating descriptions and labelled as 'Cases' A, B etc.; but they mobilize a rhetoric of scientific authority that qualifies both the credibility of what is depicted as well as the one who depicts it. Indeed there is no reason to doubt the veracity of these cases as of the kind actually encountered by Fanon.

22 "The Algerian... children like skeletons.... and the few olives that he was going to pick X's children have gone and eaten in the night" (WE, 248). A remembered scene from his military service comes to Fanon's mind, to illustrate how repression and war turn the oppressed against each other: "It was in Oran in 1944. From the camp where we were waiting to embark, soldiers were throwing bits of bread to little Algerian children who fought for them among themselves with anger and hate" (WE, 248).

${ }^{23}$ A good example here is Cannella and Viruru (2004). Lesko (1996) also mobilises Fanon, though in relation to the colonisation of youth, while Levinson (1997) connects Fanon with Arendt.

${ }^{24}$ Stoler's analysis invites further engagements with discussions of affect, to which Fanon as a psychiatrist was no stranger, and connects with a recent focus of educational debate - including Bingham (2005) which reviews several alternative models of affect, emotion and relationships, and as also applied by Burman (in press); Boler (1997) was an early instigator of such discussions. For a critical evaluation of Fanon's clinical work, see also Vergès (1996). 
35 | P a g e

${ }^{25}$ A classed reading of the heterosexed/gendered encounter between Fanon and the white woman and (boy)child in BSWM would note the public setting and public transportation, alongside how (as Ghassan, 2010 also notes) the apparently exceptional references to him that he parodies also draw attention to how his attributed middle class, professional status does not simply cancel out or offset his racialised position. In $D C$ and WE there are explicit references to class struggle as a necessary part of the revolutionary process, although much of this is assumed to be played out via rural-urban tensions (with rural peasantry coding for the working class). 